\title{
Demography of fish populations reveals new challenges in appraising juvenile habitat values
}

\author{
I. A. Kimirei ${ }^{1,2}$, I. Nagelkerken ${ }^{1,3, *}$, N. Slooter ${ }^{1}$, E. T. Gonzalez ${ }^{1}$, C. M. Huijbers ${ }^{1,6}$, \\ Y. D. Mgaya ${ }^{4}$, A. L. Rypel ${ }^{5}$
}

\begin{abstract}
${ }^{1}$ Radboud University Nijmegen, Institute for Water and Wetland Research, Department of Animal Ecology and Ecophysiology, PO Box 9010, 6500 GL Nijmegen, The Netherlands

${ }^{2}$ Tanzania Fisheries Research Institute, PO Box 90, Kigoma, Tanzania

${ }^{3}$ Southern Seas Ecology Laboratories, School of Biological Sciences and The Environment Institute, DX 650 418, The University of Adelaide, Adelaide, South Australia 5005, Australia
\end{abstract}

${ }^{4}$ Department of Aquatic Sciences and Fisheries, University of Dar es Salaam, PO Box 60091, Dar es Salaam, Tanzania

${ }^{5}$ Department of Fish and Wildlife Conservation, Virginia Tech University, 154 Cheatham Hall, Blacksburg, VA 24061-0321, USA

${ }^{6}$ Present address: Australian Rivers Institute and School of Environment, Griffith University, Gold Coast, Queensland 4222, Australia

\begin{abstract}
Understanding the 'value' of nursery habitats is increasingly perceived as essential to conservation management of marine ecosystems globally. Yet, most work on this topic has assumed that population dynamics are temporally and spatially static, which clearly oversimplifies some highly complex and integral ecological processes. We used size-frequency data of fish species from mangrove and seagrass habitats collected at various locations over a $>2$ yr period to explore demographic structure and variability along with potential factors (such as growth, food abundance, and relative predation risk) that might encourage such variability. While demographics were skewed predominantly towards juveniles, older fish (up to $13 \mathrm{yr}$ ) were regularly observed in some mangroves or seagrass beds, indicating relatively complex population demographics. Juvenile habitats varied substantially in both prey abundance and relative predation risk - an effect that appeared to give rise to habitat-specific differences in somatic growth rates and fish densities. Fish population size structure was further related to position within the seascape, suggesting complex spatial dynamics in the production of fish biomass. Our results demonstrate that effectively appraising juvenile habitats will be a more convoluted process than previously thought, as greater integration is needed between basic ecological processes (e.g. predation risk and food availability) and population demography. Whereas current approaches often identify and manage single, complete nursery habitats based on those that contribute most individuals to adult populations, our study shows that a more dynamic and spatially-explicit management approach is needed, as nurseries have divergent benefits for separate life stages, species, and locations.
\end{abstract}

KEY WORDS: Coral reef fish $\cdot$ Mangroves $\cdot$ Nursery $\cdot$ Predation $\cdot$ Seagrass beds $\cdot$ Size structure Resale or republication not permitted without written consent of the publisher

\section{INTRODUCTION}

Tropical shallow-water habitats are widely acknowledged as critical settlement and juvenile habitats for myriad coral reef fish species, many of which are commercially relevant (Beck et al. 2001, Nagel- kerken 2009). However, environmental degradation of these habitats (e.g. Valiela et al. 2001, Gillanders 2006) poses large-scale threats to the sustainability of coastal fisheries that are poorly understood (Gibson 1994, Pihl et al. 2005, Sundblad et al. 2013). Because of their importance to juveniles, these habitats are 
collectively referred to as 'nurseries' (Nagelkerken 2009), a concept that is reinforced by reduced predation risk and increased food abundance relative to adult reef habitats (Laegdsgaard \& Johnson 2001, Verweij et al. 2006).

Support for the nursery function hypothesis in nearshore habitats is largely based on the observation that high juvenile densities are found in these habitats (see reviews by Blaber 2000, Nagelkerken 2009). However, the presence or absence of juveniles in a habitat alone does not necessarily mean that it is an essential habitat for the complete life cycle of a species (Tupper \& Boutilier 1995, Rypel \& Bayne 2009). This is particularly true if the contribution of this habitat to the production of individuals in the adult population is minimal or even zero-as typically occurs in metapopulations with ecological sinks (Hanski et al. 1996, Beck et al. 2001, Adams et al. 2006). Furthermore, contradictory evidence exists in some systems that predation risk is not lowered (Baker \& Sheaves 2009a,b, Dorenbosch et al. 2009) and food availability not increased in some nursery habitats (Grol et al. 2008, Kimirei et al. 2013b).

Although many coastal environments are widely recognized to subsidize adjacent reef fish populations (Verweij et al. 2008, Mateo et al. 2010, Kimirei et al. 2013a), few studies have explored the ramifications of population variability within nursery habitats. Mangroves and seagrass beds are dynamic environments with variable fish recruitment, survival, and movement (Nagelkerken 2007), potentially leading to large and important differences in population structure and dynamics. For example, many individuals undergo ontogenetic niche shifts moving from structurally complex habitats containing predation refuges (Auster et al. 1997, Dahlgren \& Eggleston 2001) towards adult habitats supporting rapid growth but lacking refuges (Dahlgren \& Eggleston 2000, Grol et al. 2011). However, these same juvenile habitats sometimes also harbor growth-stunted resident adults that are sexually immature (Nakamura \& Sano 2004, Faunce \& Serafy 2007, Unsworth et al. 2009, Kimirei et al. 2011). It may be over-simplistic to refer to all nearshore habitats in the nursery function sense, especially considering that in-depth studies on population demography in these habitats are almost completely lacking.

The current study evaluates demographic parameters (frequency distribution, mean, skewness, kurtosis, and mode) and length-at-age data to study size structure and growth of 4 economically and ecologically relevant fish species, viz. Lethrinus harak, $L$. lentjan, Lutjanus fulviflamma, and Siganus sutor, among different coastal habitats in Tanzania. We used density data collected over a period $>2 \mathrm{yr}$ to understand the degree of population stability and to elucidate differences in growth rates among juvenile habitats, and test their correlation with potential environmental and biotic drivers, including food abundance and predation risk. This information is critical for understanding ecological processes affecting the function of coastal ecosystems, along with improving conservation management initiatives of adult fish populations on coral reefs.

\section{MATERIALS AND METHODS}

\section{Study area}

The study was conducted in mangroves and seagrass beds at 2 locations, Mbegani and Kunduchi, in Tanzania. The Mbegani area is characterized by non-estuarine mangroves, dominated by Sonneratia alba on the seaward side (Fig. 1a). Visual surveys were done in the $S$. alba root zone during high tide $(\sim 1.5 \mathrm{~m})$. Freshwater input is only substantial during the rainy season (March to May), through an intermittent river. Seagrass in the intertidal zone is dominated by Thalassia hemprichii (>60\% bottom cover). Surveys were done at approximately $2 \mathrm{~m}$ water depth in $T$. hemprichii beds. The adult habitats (coral reefs, deep mudflats) are located 6 to $9 \mathrm{~km}$ away from the mangroves (for a detailed spatial arrangement of the habitats, see Kimirei et al. 2011).

The Kunduchi area in Dar es Salaam, on the other hand, has a mangrove-lined creek (Manyema Creek), an extensive shoreline seagrass bed, and nearshore islands with shallow mudflats, seagrass beds, and fringing coral reefs which are separated from the mainland by a $15 \mathrm{~m}$ deep channel running almost parallel to the coastline (Fig. 1b). Visual surveys in the mangroves were done during high tide at $\sim 1.5 \mathrm{~m}$ water depth in the Manyema Creek, which is dominated by $S$. alba along its banks. The creek receives substantial freshwater input only during heavy rainfall. The seagrass bed along the shoreline of the mainland mainly consists of $T$. hemprichii, and ranges in depth from 0.5 to $5 \mathrm{~m}$. Fish surveys were done during high tide at $\sim 2.5$ to $3 \mathrm{~m}$ depth.

Bongoyo and Mbudya Islands are located 1.5 to $3 \mathrm{~km}$ from the Kunduchi shoreline. The vertical gradient of habitats on the islands is a shallow seagrass bed consisting of mixed species (0-2 $\mathrm{m}$ depth); a shallow fringing coral reef (2-4 $\mathrm{m}$ depth); a shallow mudflat at $4 \mathrm{~m}$ depth that is approximately $5 \mathrm{~m}$ wide; and a deeper seagrass bed (4-10 m depth) domi- 


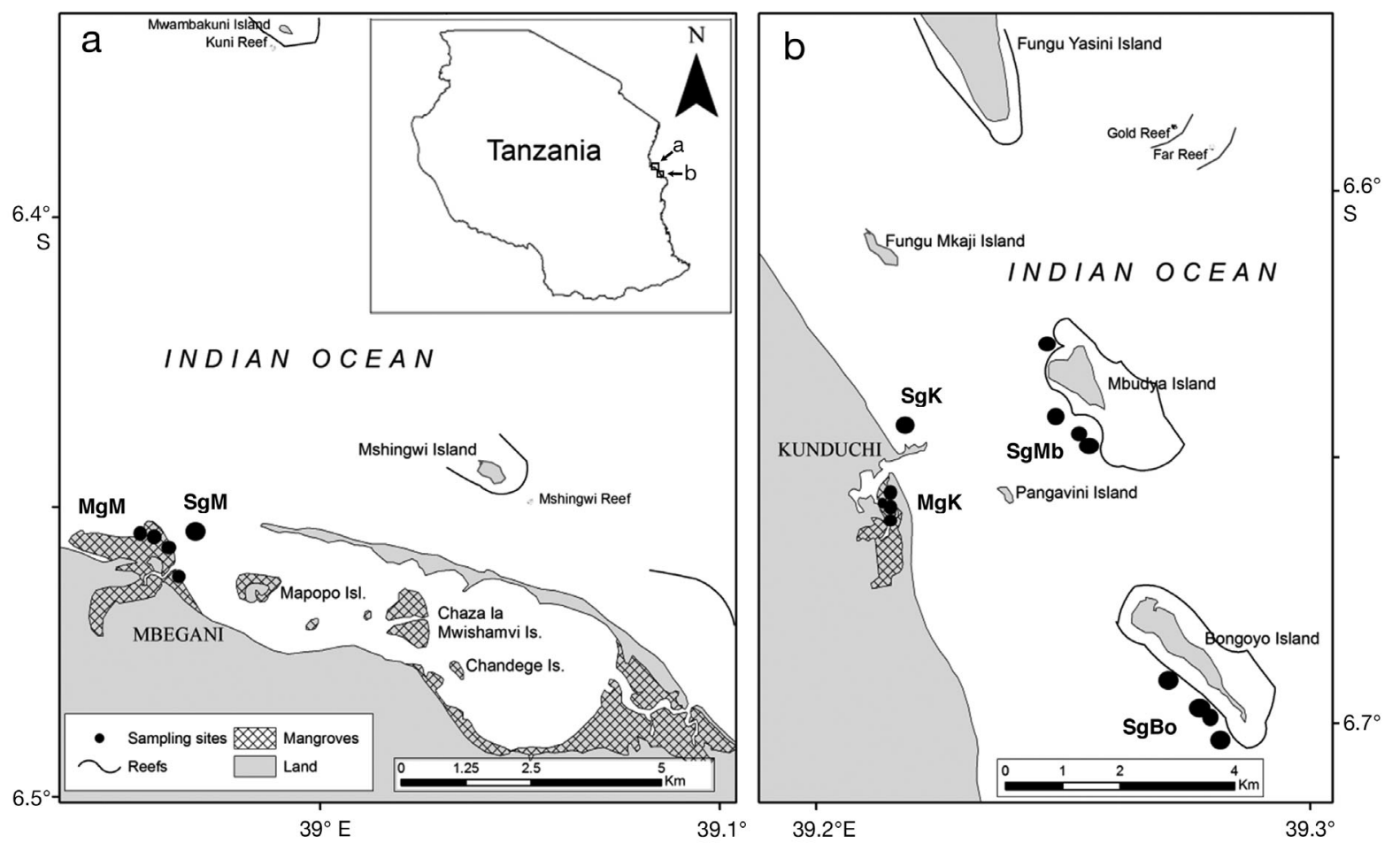

Fig. 1. Study locations in Tanzania: (a) Mbegani and (b) Kunduchi, showing all sampling sites (๑). Data were collected in mangroves and seagrass beds near the mainland at both locations, and in seagrass beds close to nearshore islands in the Kunduchi area (Mbudya and Bongoyo Islands). SgM: seagrass bed Mbegani; SgK: seagrass bed Kunduchi; SgMb: seagrass bed Mbudya; SgBo: seagrass bed Bongoyo; MgM: mangrove Mbegani; MgK: mangrove Kunduchi

nated (>60\% cover) by T. hemprichii (Kimirei et al. 2011). Visual surveys on the islands were conducted only for the deep seagrass beds.

\section{Sampling design}

The study focused on 4 economically important fish species: Lethrinus harak, L. lentjan, Lutjanus fulviflamma, and Siganus sutor. All 4 species can be described as ontogenetic shifters sensu Adams et al. (2006) (see Nakamura \& Tsuchiya 2008, Unsworth et al. 2008). In our study area, results suggest that these fish move from seagrass (primarily) and mangrove (secondarily) habitats to deeper, offshore coral reef and soft substratum habitats (Kimirei et al. 2011). Furthermore, for 3 of the species (L. harak, L. lentjan, L. fulviflamma), we confirmed for our study area, using stable carbon and oxygen isotope signatures in their otoliths, that they shift ontogenetically from nearshore vegetated habitats to deeper offshore reef areas (Kimirei et al. 2013a). The size (total length in $\mathrm{cm}, \mathrm{TL}$ ) at first maturity, defined as the size at which $50 \%$ of all individuals were mature, was about $17 \mathrm{~cm}$ for $L$. harak in seagrass beds, $14 \mathrm{~cm}$ for $L$. lentjan in seagrass beds, and $16 \mathrm{~cm}$ for $L$. fulviflamma in mangroves and seagrass beds (Kimirei et al. 2013b). Size at first maturity for $S$. sutor is approx. $22 \mathrm{~cm}$ (Kamukuru 2009).

Density and size (TL) estimations of the 4 species were performed in mangroves and seagrass beds during daytime using underwater visual census (Nagelkerken et al. 2000b). The advantages and disadvantages of this method are discussed by English et al. (1994). To minimize disturbance to fishes, divers swam transects at a speed no more than $10 \mathrm{~m} \mathrm{~min}^{-1}$ and unrolled the transect line while counting target fish species and estimating sizes.

Fish size, density, and species recognition were practiced thoroughly in the field prior to census commencement. Size estimation was practiced by estimating sizes of objects (of different sizes at different distances) underwater and measuring actual sizes following estimation; this was continued until size estimation was precise. Size estimation was also repeated regularly during the study period so as to eliminate any discrepancy in estimation over time. Multiple, spatially $(>30 \mathrm{~m}$ ) separated belt transects $(4 \mathrm{~m}$ wide $\times$ $50 \mathrm{~m}$ long) were randomly placed at each study site. Sites were relocated using a GPS (Map 60, Garmin). About 3 transects were sampled per mangrove or seagrass site at Mbegani and Kunduchi, while at Mbudya 
and Bongoyo Islands, 1 or 2 transects per site were sampled for each census. All censuses were performed during neap tide over 25 successive months (March 2007 to March 2009). The target sampling effort was twice per month, depending on weather conditions and water clarity. In total 112, 178, 186, and 80 replicate transects were censused in the seagrass beds at Mbegani, Bongoyo Island, Mbudya Island, and Kunduchi, respectively; for the mangroves at Mbegani and Kunduchi, the numbers of replicate transects were 172 and 113, respectively. For each of the 6 (see Fig. 1) habitat/location combinations (further referred to as 'habitat types'), data were averaged across sites and months to account for the differences in sampling effort. Snorkeling was used to survey shallow seagrass beds at Mbudya and Bongoyo Islands and in the mangroves at Kunduchi and Mbegani, while SCUBA diving was used for the deep seagrass beds at Mbudya and Bongoyo Islands.

Environmental variables (seawater temperature, salinity, water clarity, and survey depth) were measured on each survey day (approx. every 2 wk). Seawater temperature and salinity were measured using a Hach SensIon5 conductivity meter, while water clarity (horizontal Secchi distance) was measured using a transect line. All environmental variables were measured at the surface, except visibility, which was measured at the same depth as where the fish censuses were done.

Individuals of 3 fish species (L. lentjan, L. fulviflamma, and S. sutor) were collected from the mangroves and seagrass beds for age estimation by analysis of otolith sagittae. Fishes from the mangroves were collected at low tide from creeks that remained partly inundated and therefore represent mangroveassociated fish rather than fish showing tidal movements between mangroves and seagrass beds. The number of otoliths aged for each species were: $L$. lentjan (mangrove: 0; seagrass: 125), L. fulviflamma (86, $159)$, and $S$. sutor $(0,44)$. Insufficient specimens of $L$. harak were obtained for this species to be included. All fish collections took place at approximately the same sites, but on different days, as the underwater visual census surveys. Due to continuous inflow and outflow of fishes with the tides, the collection of the fishes for otolith analysis is unlikely to have had any effect on the fish densities. Fishes from mangrove habitat were collected with a $1 \times 10 \mathrm{~m}$ seine dragged against the current during outgoing tide (towards the end of ebbing tide). Hook and line angling and a fyke net were used at low tide to supplement fish catch in the mangrove habitat and guard against gear selectivity in fish size. Fishes from the seagrass beds were purchased from local fishermen who used beach seines at low tide. Otolith sagittae were removed and used to estimate the age of each fish. Each otolith was cross-sectioned using standard methodology (Maceina 1988) and examined under a dissecting microscope utilizing reflected light. Ages were determined blindly (i.e. with no knowledge of the sample number or fish size) twice by an experienced reader, and discrepancies between reads 1 and 2 (4\% of all samples) were settled using another experienced reader.

Potential fish prey items were sampled using a $50 \times$ $50 \mathrm{~cm}$ quadrat, which was randomly placed at each study site. All flora and loose substrate within the quadrat were then collected by hand and placed into a bag. Only epifauna were collected because the studied fish species feed on slow-moving prey on the substratum or those associated with the vegetation (Carpenter 1996), while S. sutor is a herbivore. For seagrass beds, all seagrass shoots were carefully cut and collected into a hand-closed plastic bag to minimize escape of prey. For mangroves, the roots were cut off and all loose pieces collected in a plastic bag. A total of 6 and 13 quadrats (replicates) were sampled in the mangrove and seagrass habitats, respectively (for details, see Kimirei et al. 2013b).

Differences in relative predation risk among habitats were estimated using tethering experiments with one of the focal species ( $L$. fulviflamma). Insufficient specimens were available to conduct experiments using the other species. Although only 1 species was tested, juveniles of the 2 Lethrinus species showed very similar behavior and habitat use. Relative predation risk for L. fulviflamma does not provide exact measures for predation risk of the other species, but considering the large differences in predator size and densities across habitats it is likely that habitat has a larger effect on predation risk of these juvenile fish in this case than fish species per se. Such an approach has previously also been used in other studies comparing coastal habitats (e.g. Hammerschlag et al. 2010). Fish of 1 to $4 \mathrm{~cm}$ TL were tethered during daytime at all seagrass and mangrove locations following the protocol of Dorenbosch et al. (2009). Individuals were attached by a barbed hook through the lower jaw to a light monofilament line (50-80 cm length). The line was attached to an iron pole $(\sim 40 \mathrm{~cm}$ height) that was anchored into the substratum. The monofilament line was rated at $\sim 5 \mathrm{~kg}$ breaking force, ensuring that fish could not cut loose from the line. Fish were able to hide within the surrounding vegetation on the seagrass beds, or between the mangrove roots. Each tethering trial lasted $90 \mathrm{~min}$, and at 30,60, and $90 \mathrm{~min}$ following placement, we assessed whether the fish 
was alive (i.e. survived) or had clearly been attacked or eaten (i.e. hook and/or part of the line missing). Fish that were dead on the hook or detached (i.e. line and hook undamaged) were excluded from the analysis. One trial was conducted for each habitat per site, during which 9 to 14 fish (replicates) were tethered simultaneously. The time interval at which a fish was found missing from the tether (i.e. either 30,60, or $90 \mathrm{~min}$ ) was noted and averaged across individuals for each habitat per location. Other studies have also used similar tethering durations as the present study (Shulman 1985, Dorenbosch et al. 2009, Hammerschlag et al. 2010). Although tethering experiments are commonly used to measure relative predation potential/risk in fishes and invertebrates (e.g. Shulman 1985, Wilson et al. 1990, Dahlgren \& Eggleston 2000, Baker \& Sheaves 2007, Dorenbosch et al. 2009, Kimirei et al. 2013b, Grol et al. 2014), they also produce biases/artifacts that can confound results (see Peterson \& Black 1994). Nonetheless, possible tethering artifacts among treatments were comparatively similar since the same tethering method was used across all habitats (Aronson \& Heck 1995).

\section{Data analysis}

To evaluate demographic patterns, average densities per species, per $1 \mathrm{~cm}$ size and $0.5 \mathrm{yr}$ age classes, per habitat, and per location were computed across months and years, and used for size/age-frequency analysis. To transform the size-frequency graphs (see Fig. 2) to age-frequency graphs (see Fig. 3), fish sizes were converted into age (see age analysis below) using equations derived from age-length regressions specific to species and habitats (because of the difference in regressions across species and habitats; see Fig. 4). Demographic shape parameters (mean, standard deviation, mode, skewness, kurtosis, and the probability that data were normally distributed) were computed for size and age distributions. Frequency distributions were compared to a normal distribution and to one another using 1-sample KolmogorovSmirnov (K-S) tests and 2-sample K-S tests, respectively. In total, there were 15 frequency-distribution comparisons per species, with a Bonferroni correction for the 2-sample K-S tests.

Growth analysis was based on fish age obtained from the otolith analyses. For each species, fish growth was modeled using the Von Bertalanffy Growth Function, $L_{t}=L_{\infty}\left(1-\mathrm{e}^{-k\left(t-t_{0}\right)}\right)$, where $L_{t}=$ length at time $t, L_{\infty}=$ the theoretical maximum length, $k=$ a growth coefficient (the rate at which length approaches $\left.L_{\infty}\right), t=$ fish age in years, and $t_{0}=$ theoretical time at age 0 . However, because growth is completed over several habitat types, and is generally non-asymptotic, differences in growth between habitats for each species (e.g. seagrass versus mangrove) were evaluated using analysis of covariance (ANCOVA) combined with Tukey's post hoc tests. In these models, TL was the dependent variable, $\log _{10}$ (age) was a covariate, and habitat type was a categorical variable (Rypel 2011).

Similarity among habitat types in fish sizefrequency distributions (see Fig. 2) was analyzed using the program PRIMER version 6 (Clarke \& Warwick 2001). Fish densities were first averaged across sites and transects within habitat types. All data were then square-root transformed, and Bray-Curtis similarity coefficients were calculated among the habitat types. The potential relationship between environmental variables (standardized by subtracting the mean and dividing by the standard deviation for that variable) and the fish size-frequency distributions were then assessed, for each fish species separately, using the BIO-ENV procedure (Clarke \& Warwick 2001), which calculates the correlation (Spearman rank) between the similarity matrices of the biological (Bray-Curtis) and environmental (Euclidean) data. All significances for the above tests were calculated on the basis of 999 permutations. The environmental factors consisted of seawater temperature, salinity, water clarity, and survey water depth, while the biological factors consisted of survival from predation (for one target species) and total density of available prey items. These data were collected in the same habitats as the fish data. Only prey items for zoobenthivorous fishes were quantified, and for the current study this consisted of the summed density of all worms, amphipods, crabs, and shrimps counted in replicate $50 \times 50 \mathrm{~cm}$ quadrats per habitat. The food items considered in the analysis were confirmed to be the focal food resources for the selected species through stomach content analysis of the same individuals as caught for age determination; these diet data are reported elsewhere (Kimirei et al. 2013b).

\section{RESULTS}

\section{Demographic structure}

Thirteen $(57 \%)$ of the 23 size-frequency distributions and $9(45 \%)$ of the 20 age-frequency distributions followed a normal distribution (Table 1). Skewness $\left(g_{1}\right)$, a parameter that describes symmetry 
around the mean of a frequency distribution, was positive for all 23 and 20 cases for length and age, respectively, indicating that the distributions were asymmetrical around the mean, in favor of small and young individuals. Kurtosis $\left(g_{2}\right)$ is a parameter which describes the peakedness of a distribution near its central mode. Almost all distributions were peaked (i.e. leptokurtic: $g_{2}>0$ ), and some species showed

Table 1. Distribution parameters of density data for 4 fish species in 2 habitats at different locations (4 seagrass beds: Mbegani, Kunduchi, Mbudya, and Bongoyo; and 2 mangroves: Mbegani and Kunduchi) for (a) total length and (b) age. SD: standard deviation; Pnorm: probability that data are from a normal distribution (if Pnorm > 0.05; one-sample Kolmogorov-Smirnov test using Lilliefors adjusted probability); $g_{1}$ : skewness; $g_{2}$ : kurtosis; $\mathrm{n}$ : total number of individuals observed in the field

\begin{tabular}{|c|c|c|c|c|c|c|c|c|c|}
\hline $\begin{array}{l}\text { (a) Total length } \\
\text { Species }\end{array}$ & Habitat & Location & Mean length & $\mathrm{SD}$ & $g_{1}$ & $g_{2}$ & Pnorm & Mode length & h $\mathrm{n}$ \\
\hline \multirow[t]{6}{*}{ Lethrinus harak } & \multirow[t]{4}{*}{ Seagrass } & Mbegani & 7.1 & 2.8 & 1.8 & 3.3 & 0.186 & 6 & 648 \\
\hline & & Kunduchi & 10.5 & 5.9 & 1.2 & 0.4 & 0.113 & 5 & 22 \\
\hline & & Mbudya & 18.9 & 3.6 & 4.0 & 16.9 & 0.003 & 21 & 217 \\
\hline & & Bongoyo & 20.8 & 0.4 & 4.1 & 17.1 & $<0.001$ & 21 & 9 \\
\hline & \multirow[t]{2}{*}{ Mangrove } & Mbegani & 13.5 & 5.4 & 1.7 & 2.9 & 0.082 & 12 & 26 \\
\hline & & Kunduchi & 9.0 & 1.4 & 3.0 & 7.6 & $<0.001$ & 8 & 2 \\
\hline \multirow[t]{6}{*}{ Lethrinus lentjan } & \multirow[t]{4}{*}{ Seagrass } & Mbegani & 7.0 & 2.8 & 1.2 & 0.3 & 0.219 & 5 & 234 \\
\hline & & Kunduchi & 9.3 & 4.5 & 1.9 & 2.6 & 0.001 & 5 & 10 \\
\hline & & Mbudya & 7.6 & 3.0 & 1.7 & 2.4 & 0.108 & 5 & 849 \\
\hline & & Bongoyo & 7.9 & 3.0 & 1.7 & 1.9 & 0.065 & 5 & 295 \\
\hline & \multirow[t]{2}{*}{ Mangrove } & Mbegani & 7.3 & 2.0 & 1.7 & 2.1 & 0.003 & 6 & 11 \\
\hline & & Kunduchi & 8.0 & 0.0 & 4.6 & 21.0 & $<0.001$ & 8 & 2 \\
\hline \multirow[t]{6}{*}{ Lutjanus fulviflamma } & \multirow[t]{4}{*}{ Seagrass } & Mbegani & 6.8 & 2.2 & 1.7 & 2.2 & 0.030 & 5 & 444 \\
\hline & & Kunduchi & 6.9 & 2.9 & 2.2 & 5.6 & 0.110 & 5 & 127 \\
\hline & & Mbudya & 17.5 & 3.3 & 1.3 & 0.4 & 0.071 & 21 & 98 \\
\hline & & Bongoyo & 7.7 & 1.2 & 3.5 & 12.6 & $<0.001$ & 7 & 3 \\
\hline & \multirow[t]{2}{*}{ Mangrove } & Mbegani & 8.8 & 3.5 & 1.2 & 0.4 & 0.100 & 10 & 271 \\
\hline & & Kunduchi & 9.8 & 4.1 & 0.8 & -0.8 & 0.252 & 10 & 367 \\
\hline \multirow[t]{5}{*}{ Siganus sutor } & \multirow[t]{4}{*}{ Seagrass } & Mbegani & 5.2 & 2.8 & 2.5 & 6.7 & 0.090 & 3 & 1887 \\
\hline & & Kunduchi & 3.4 & 1.3 & 3.2 & 11.3 & 0.009 & 3 & 21492 \\
\hline & & Mbudya & 7.6 & 3.9 & 1.8 & 2.9 & 0.086 & 5 & 3838 \\
\hline & & Bongoyo & 7.2 & 5.0 & 3.7 & 15.6 & 0.077 & 2 & 2958 \\
\hline & Mangrove & Kunduchi & 8.7 & 4.1 & 3.5 & 12.9 & 0.001 & 13 & 28 \\
\hline \multicolumn{10}{|l|}{ (b) Age } \\
\hline Species & Habitat & Location & Mean age & $\mathrm{SD}$ & $g_{1}$ & $g_{2}$ & Pnorm & Mode age & $\mathrm{n}$ \\
\hline \multirow[t]{6}{*}{ L. harak } & \multirow[t]{4}{*}{ Seagrass } & Mbegani & 3.0 & 1.6 & 2.1 & 3.9 & 0.054 & 2 & 648 \\
\hline & & Kunduchi & 3.7 & 2.2 & 1.6 & 2.5 & 0.240 & 2 & 22 \\
\hline & & Mbudya & 3.8 & 1.9 & 3.1 & 10.2 & 0.085 & 7.5 & 217 \\
\hline & & Bongoyo & 6.7 & 0.0 & 2.7 & 7.0 & 0.002 & 7.5 & 9 \\
\hline & \multirow[t]{2}{*}{ Mangrove } & Mbegani & 4.2 & 1.9 & 2.3 & 4.1 & 0.259 & 4 & 26 \\
\hline & & Kunduchi & 2.4 & 0.3 & 1.4 & 1.0 & 0.003 & 3 & 2 \\
\hline \multirow[t]{4}{*}{ L. lentjan } & \multirow[t]{4}{*}{ Seagrass } & Mbegani & 3.2 & 1.6 & 2.5 & 6.1 & 0.013 & 2 & 234 \\
\hline & & Kunduchi & 3.0 & 1.5 & 2.3 & 4.9 & 0.001 & 2 & 10 \\
\hline & & Mbudya & 3.9 & 2.4 & 2.7 & 7.2 & 0.022 & 2 & 849 \\
\hline & & Bongoyo & 3.9 & 2.4 & 2.6 & 6.1 & 0.009 & 2 & 295 \\
\hline \multirow[t]{6}{*}{ L. fulviflamma } & \multirow[t]{4}{*}{ Seagrass } & Mbegani & 2.6 & 1.4 & 2.2 & 3.8 & 0.004 & 2 & 444 \\
\hline & & Kunduchi & 2.6 & 1.3 & 3.1 & 10.5 & 0.034 & 1.5 & 127 \\
\hline & & Mbudya & 6.2 & 2.5 & 1.1 & 0.2 & 0.160 & 6 & 98 \\
\hline & & Bongoyo & 1.9 & 0.0 & 4.4 & 19.0 & $<0.001$ & 2 & 3 \\
\hline & \multirow[t]{2}{*}{ Mangrove } & Mbegani & 4.3 & 2.8 & 1.7 & 1.7 & 0.017 & 1.5 & 271 \\
\hline & & Kunduchi & 4.4 & 3.6 & 1.5 & 0.6 & 0.006 & 2 & 367 \\
\hline \multirow[t]{4}{*}{ S. sutor } & Seagrass & Mbegani & 1.6 & 0.6 & 1.5 & 0.7 & 0.378 & 1.5 & 1887 \\
\hline & & Kunduchi & 1.4 & 0.5 & 1.9 & 2.9 & 0.087 & 1 & 21492 \\
\hline & & Mbudya & 2.1 & 0.9 & 2.3 & 5.6 & 0.607 & 1.5 & 3838 \\
\hline & & Bongoyo & 2.1 & 0.9 & 0.8 & -0.9 & 0.651 & 1 & 2958 \\
\hline
\end{tabular}


extreme peakedness in some habitats, which can be partly explained by recruitment peaks. The population structure of all 4 species was dominated by small individuals (18 of 23 length modes $\leq 10 \mathrm{~cm} \mathrm{TL}$ ). The mode for age varied largely between 1 and $4 \mathrm{yr}$, although some individuals stayed in seagrass beds up to an age of $11 \mathrm{yr}$ and in mangroves up to $13 \mathrm{yr}$ (see Fig. 3).

Size/age-frequency distributions revealed variations among habitats and locations in size and age modes (Figs. 2 \& 3). Differences were generally caused by distributions being skewed either towards the smaller or towards the larger size and age classes. In addition, some habitats at some locations harbored a wide range of fish sizes and ages, while others were only represented by few size or age classes. Across species, the largest and oldest individuals were most often observed at the seagrass beds of Mbudya and Bongoyo islands as opposed to the seagrass beds along the mainland.

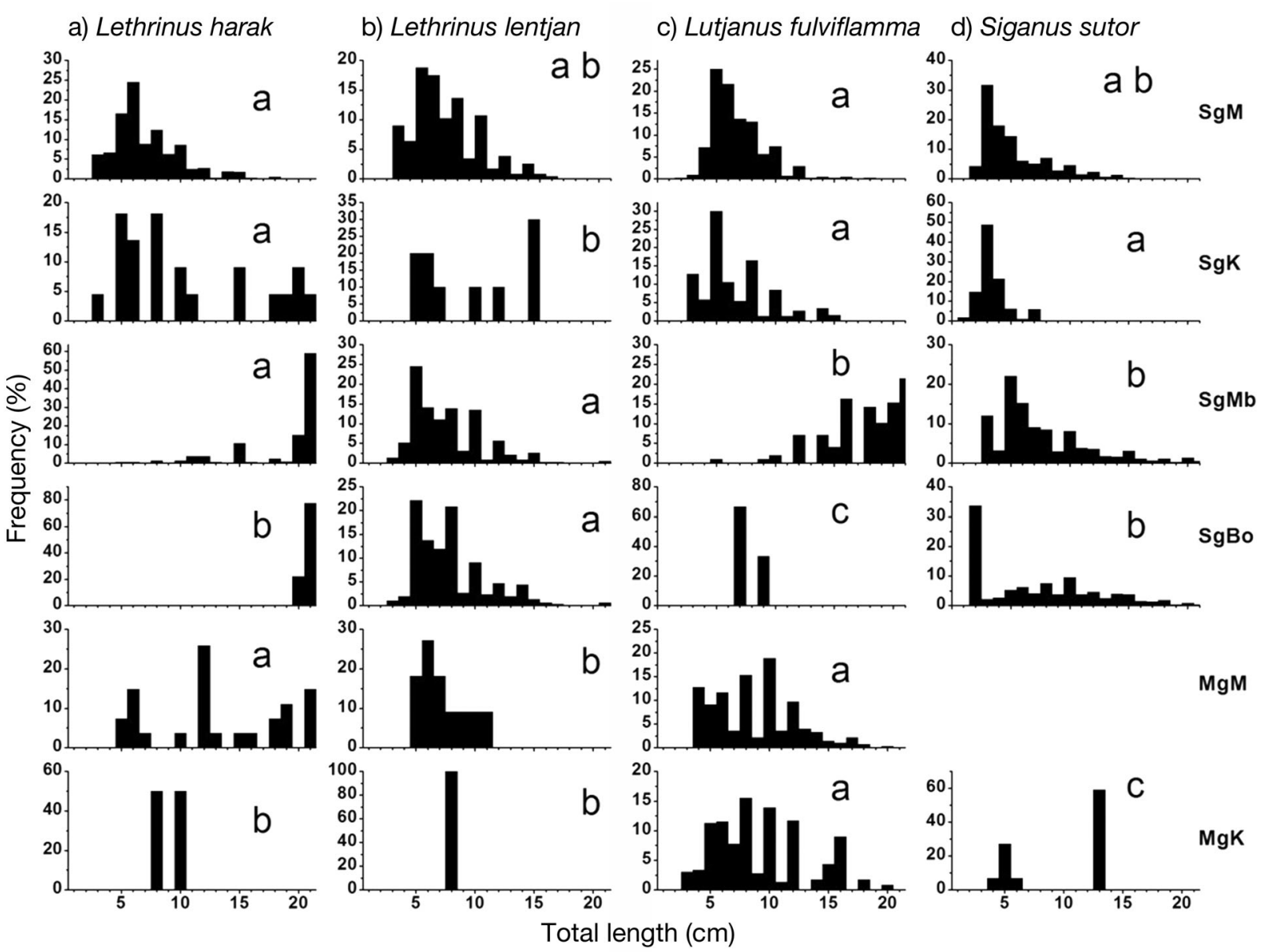

Fig. 2. Frequency distributions (on basis of total length) of 4 fish species from 2 main juvenile habitats (seagrass bed and mangroves) from 2 spatially separated locations (Mbegani and Kunduchi). Note different scales on the vertical axes. Letters show significant differences $(\mathrm{p}<0.05)$ in the shape of the distributions among the various habitats for each fish species, based on 2-sample Kolmogorov-Smirnov tests and a Bonferroni correction. See habitat abbreviations in legend of Fig. 1 


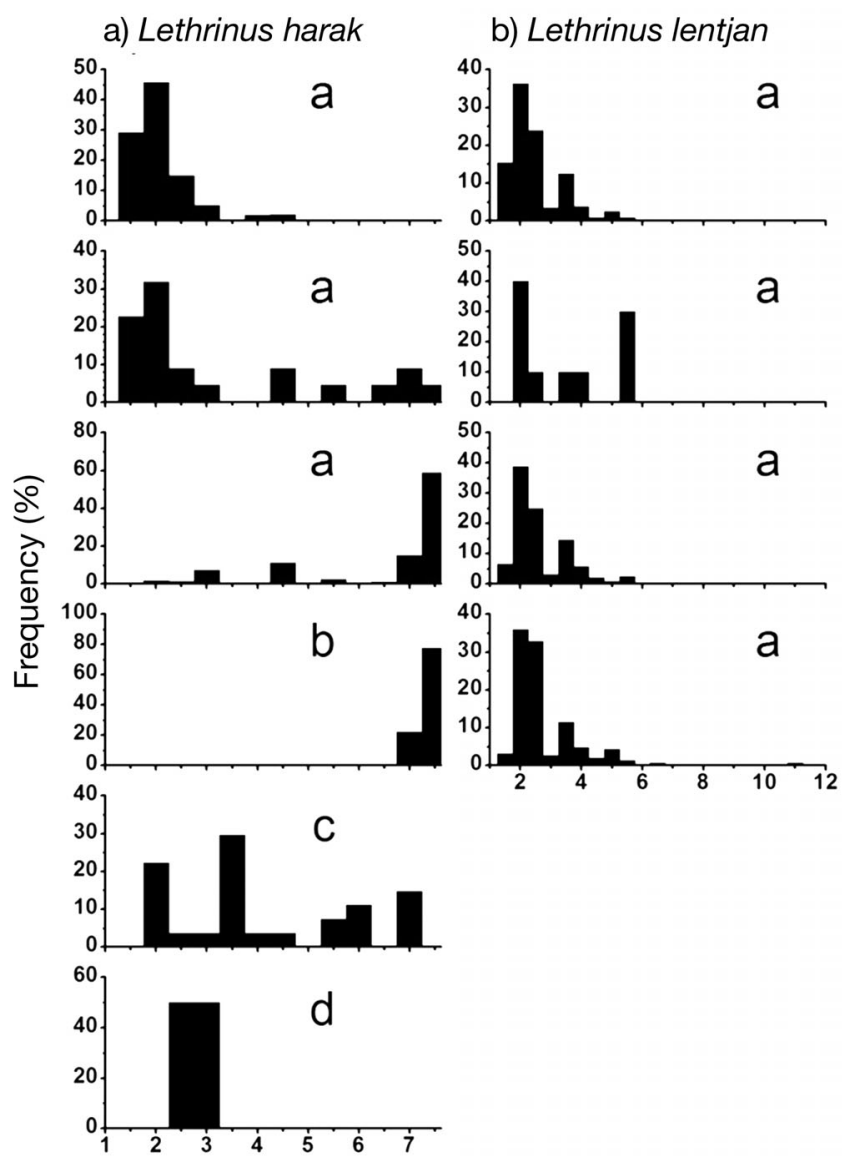

c) Lutjanus fulviflamma

d) Siganus sutor
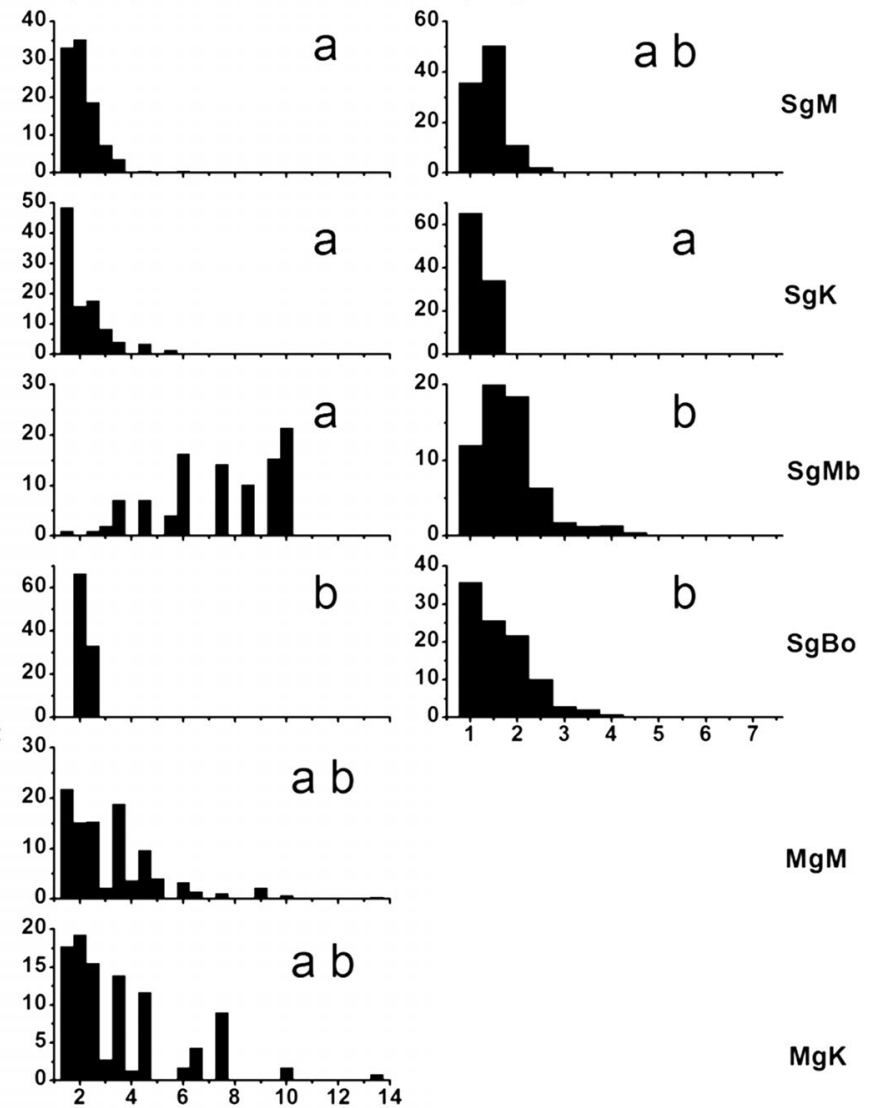

MgM

$\mathrm{MgK}$

Age (yr)

Fig. 3. Frequency distributions (on basis of age, in 0.5 yr increments) of 4 fish species from 2 main juvenile habitats (seagrass bed and mangroves) from 2 spatially separated locations (Mbegani and Kunduchi). Note different scales on the vertical axes. Letters show significant differences $(\mathrm{p}<0.05)$ in the shape of the distributions among the various habitats for each fish species, based on 2-sample Kolmogorov-Smirnov tests and a Bonferroni correction. See habitat abbreviations in legend of Fig. 1

habitat types, but with food only increasing the correlation coefficient to a small degree (BIOENV, R = 0.711 for temperature vs. $\mathrm{R}=0.752$ for temperature and food). For L. fulviflamma, water depth alone best explained the similarity in size-frequencies among habitat types (BIOENV, $\mathrm{R}=0.466$ ), and the offshore seagrass beds at Mbudya and Bongoyo Islands har- bored the highest abundances of large- $(\sim>17 \mathrm{~cm})$ and intermediate- $(\sim 7-9 \mathrm{~cm})$ sized fishes, respectively (Fig. 2c). For Siganus sutor, temperature alone best explained the similarity in size-frequencies among habitat types (BIOENV, $\mathrm{R}=0.606$ ). Temperature correlated to the size-distribution patterns for 3 of the 4 species and was higher in mangroves than in seagrass

Table 2. Mean (SD) values of various environmental and biological factors in the different mangrove and seagrass habitats and locations. Food items are presented as the summed density of all worms, amphipods, crabs, and shrimps counted in replicate $50 \times 50 \mathrm{~cm}$ quadrats per habitat. Survival from predation is based only on experiments with Lutjanus fulviflamma as prey

\begin{tabular}{|lcccccc|}
\hline Location & $\begin{array}{c}\text { Temperature } \\
\left({ }^{\circ} \mathrm{C}\right)\end{array}$ & $\begin{array}{c}\text { Salinity } \\
(\%)\end{array}$ & $\begin{array}{c}\text { Water clarity } \\
(\mathrm{m})\end{array}$ & $\begin{array}{c}\text { Depth } \\
(\mathrm{m})\end{array}$ & $\begin{array}{c}\text { Food } \\
\left(\text { ind. m }^{-2}\right)\end{array}$ & $\begin{array}{c}\text { Survival from predation } \\
(\mathrm{min})\end{array}$ \\
\hline Mangrove Mbegani & $29.4(2.7)$ & $33.9(1.6)$ & $3.2(1.1)$ & $1.2(0.3)$ & $79.9(42.5)$ & $71(36)$ \\
Mangrove Kunduchi & $29.8(2.3)$ & $33.8(1.2)$ & $2.1(0.2)$ & $1.3(0.4)$ & $17.2(32.7)$ & $17(26)$ \\
Seagrass Mbegani & $28.3(1.8)$ & $33.7(1.1)$ & $6.6(0.7)$ & $2.1(0.7)$ & $13.2(13.0)$ & $75(30)$ \\
Seagrass Kunduchi & $28.3(1.3)$ & $35.7(2.6)$ & $3.7(1.5)$ & $3.0(2.4)$ & $48.0(22.6)$ & $23(30)$ \\
Seagrass Mbudya & $28.4(1.4)$ & $34.3(0.8)$ & $7.2(0.9)$ & $5.5(0.7)$ & $37.1(43.5)$ & $66(36)$ \\
Seagrass Bongoyo & $28.4(1.4)$ & $34.2(2.1)$ & $7.5(1.9)$ & $5.5(1.2)$ & $15.2(3.9)$ & $9(20)$ \\
\hline
\end{tabular}


beds (Table 2); however, other non-measured (a)biotic factors that are collinear with temperature and that typically differ between mangrove and seagrass habitats may have been responsible for this pattern.

\section{Growth}

Length-at-age differed among habitats and locations for all species, indicating that juveniles of these species had different growth rates in different juvenile habitat types (Fig. 4). Length-at-age for L. lentjan was significantly reduced (ANCOVA, $F_{1,31}=97.6$, $\left.\mathrm{p}<0.001, \mathrm{r}^{2}=0.8\right)$ in the seagrass bed at Mbegani compared to the other 2 seagrass locations which had similar growth rates $(\mathrm{p}=0.171)$. Juveniles of $L$. fulviflamma had a significantly larger size-at-age in the mangroves than in the seagrass bed at Mbegani $\left(\right.$ ANCOVA, $\left.F_{1,23}=559.5, \mathrm{p}<0.001, \mathrm{r}^{2}=0.9\right)$. Lengthat-age for $S$. sutor juveniles in seagrass beds varied significantly in the order Mbudya > Mbegani > Bongoyo (ANCOVA, $F_{1,35}=279.4, \mathrm{p}<0.001, \mathrm{r}^{2}=0.9$ ).

In contrast to the growth differences (Fig. 4), sizefrequency distributions of $L$. lentjan and $L$. fulvi-

a) Lethrinus lentjan

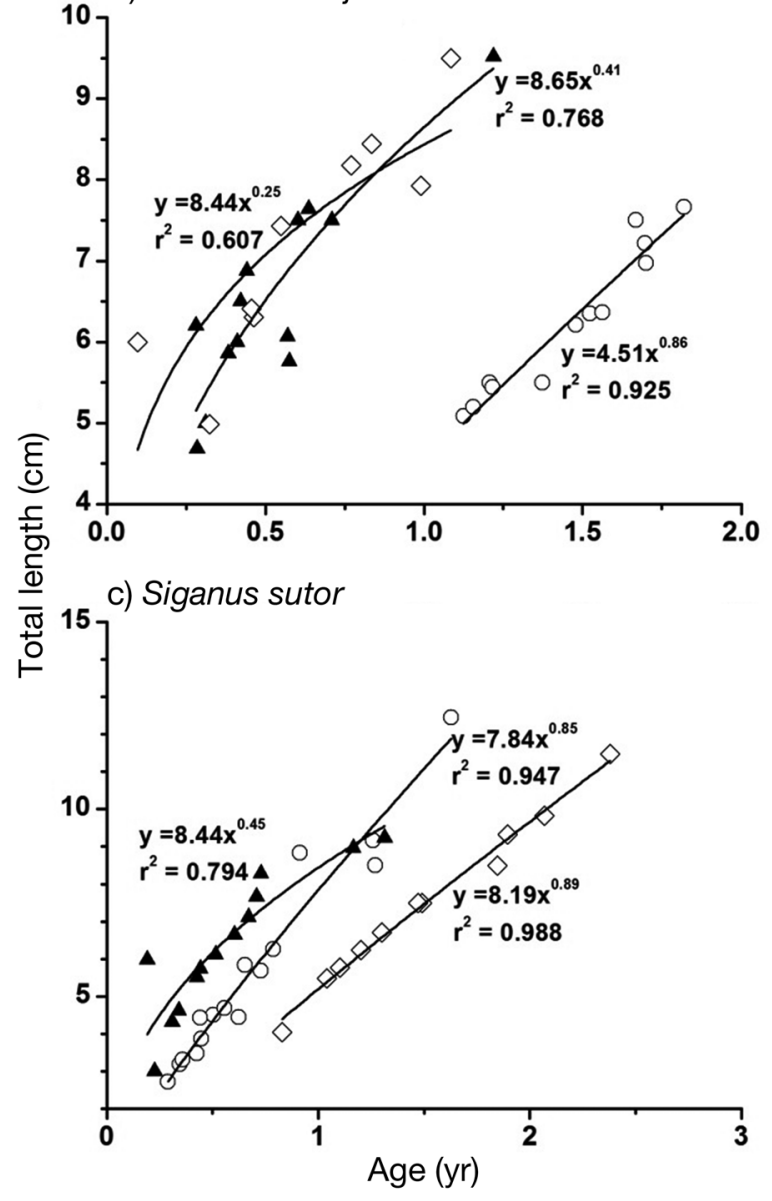

flamma did not differ in shape among the mangroves and seagrass beds for which length-at-age was determined (Fig. 2). However, total potential food abundance varied among juvenile habitat types and mirrored habitat differences for the 2 zoobenthivorous fish species in somatic growth rates. Potential food abundance for $L$. lentjan and L. fulviflamma was lowest in the seagrass bed at Mbegani, highest at Mbudya seagrass beds and Mbegani mangroves, and intermediate at Bongoyo seagrass beds (Table 2).

\section{DISCUSSION}

Coastal marine habitats are regularly and rightly acknowledged for being critical nursery areas for juvenile coral reef fishes (Parrish 1989, Beck et al. 2001, Nagelkerken 2009). Yet, while species clearly depend on these habitats during juvenile life stages, this does not imply that all nearshore habitats function equally in their nursery potential (Gillanders et al. 2003, Nagelkerken \& van der Velde 2004, Sheaves 2005, Sheaves et al. 2010, Kimirei et al. 2011, Huijbers et al. 2013). The present study revealed high

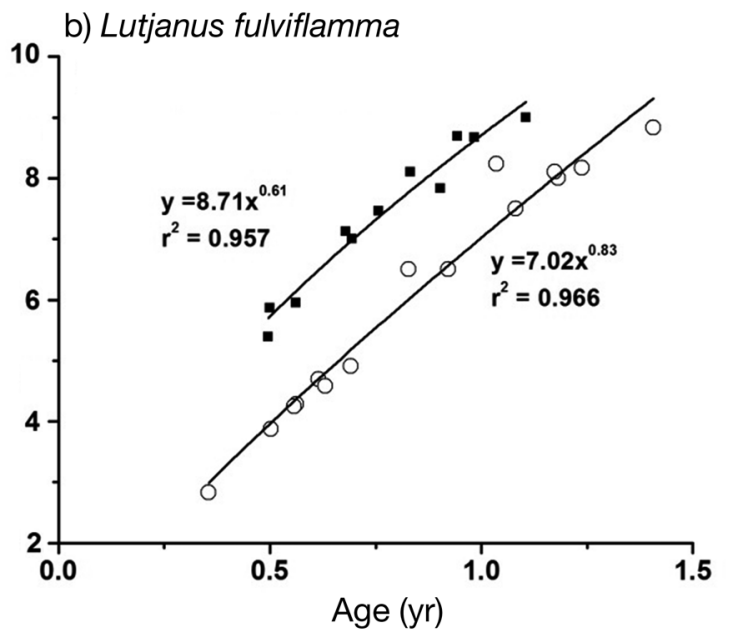

\footnotetext{
$\bigcirc$ Sg Mbegani $\Delta$ Sg Mbudya

$\diamond$ Sg Bongoyo $\quad$ Mg Mbegani
}

Fig. 4. Length-at-age relationships for 3 fish species in mangrove and seagrass habitats at various locations fitted to a power function (allometric). Sg: seagrass; Mg: mangroves. Age was based on analysis of otolith growth rings 
juvenile densities at many shallow-water sites harboring mangrove or seagrass vegetation. However, larger size classes composed of older, non-reproductive fish (see Kimirei et al. 2013b) were frequently intermingled with juveniles in varied numbers. Some habitats harbored predominantly small individuals, some harbored mainly large specimens, while others harbored small individuals as well as large adults. This finding indicates that mangrove and seagrass habitats can function quite differently and have divergent benefits for separate life stages, species, and locations.

Seascape structure (i.e. the spatial mosaic and patterning of habitat patches at the landscape level) could play a major role in the differential responses of demography to habitat (Dorenbosch et al. 2006, Olds et al. 2012). While the present study was not focused on relating specific seascape metrics to fish population metrics, some clear patterns emerged that appeared to be linked to the larger-scale seascape structure at our study sites. Mangroves were colonized at high tide by a wide size and age range of Lutjanus fulviflamma. Mangrove habitats are often not permanently accessible by fish, especially in the Indo-Pacific region, due to high tidal ranges of several meters. This tidal variability creates accessibility windows for fish to these habitats whereby mangroves can only be transiently accessed during high tides (Sheridan 1997, Sheaves 2005, Lugendo et al. 2007). Thus, the 'value' of these mangrove habitats and their suitability as juvenile habitats likely differs from ecosystems in which mangroves are perpetually connected (e.g. in the Caribbean: Nagelkerken 2009, Jones et al. 2010). Utilization of more 'temporary' habitats by small/juvenile fishes clearly can present fitness advantages (e.g. lower predation risk: Sheaves $2001,2005)$. However, our data show that mangroves were also frequently used by large individuals, suggesting that this habitat also provides some benefit to older, adult fish. This benefit can be related to the structural complexity of mangroves (Huijbers et al. 2011), yet in our study, mangroves at Mbegani had higher food abundance than the adjacent seagrass beds, and growth rates were higher in mangroves than the seagrass beds for all size classes of L. fulviflamma. Thus, overlap in mangrove habitat use by juvenile and adults in our study area might also be facilitated by high food abundances that enhanced somatic growth.

Seagrass beds showed a stronger disparity in sizeand age-class distributions compared to mangroves. Whereas seagrass beds along the continental coastline harbored a wide range of sizes for all species, the largest/oldest specimens were mainly found in seagrass beds at greater depths surrounding the nearshore islands. For Lethrinus harak and L. fulviflamma, the islands' seagrass beds did not harbor any small individuals. The close proximity of coral reefs and deeper waters give the islands' seagrass habitats the potential of being used by larger reef predators, which was most evident at Bongoyo Island that showed the lowest of all relative survival rates for $L$. fulviflamma. Seagrass beds away from mangroves may therefore provide less fitness benefits for smaller predation-prone individuals than shallower and shoreline seagrass beds isolated from reefs.

In contrast to the prevailing paradigm that nearshore habitats are exclusively nursery areas for small, juvenile fishes (Parrish 1989, Nagelkerken 2009), our study revealed that these habitats are also frequently utilized for long-term residency by adult fishes. Fishes that colonize mangrove and seagrass beds during settlement apparently can remain in these habitats for long periods (Gillanders et al. 2003), in our case up to an age of $13 \mathrm{yr}$. In fact, in our study the majority of individuals in these habitats were older than $13 \mathrm{mo}$, a pattern that differs substantially from that observed for different species and ecosystems (Gillanders et al. 2003). These important variations in fish demography of coastal habitats have implications for habitat productivity and population/ecosystem connectivity (Sheaves 2009). Longterm residence by larger adult predators in putative juvenile nursery habitats affects fish communities. Larger fish would likely act as stronger competitors to juveniles utilizing more food sources (Almany 2004, Baker \& Sheaves 2005), and could alter (i.e. delay) the timing of ontogenetic diet shifts of juveniles from macrofauna to fish (Kamukuru \& Mgaya 2004, Dorenbosch et al. 2009). Larger fish may also become predators on the juveniles themselves, either inter-specifically (Sheaves 2001) or via cannibalism (Manica 2002). Thus, some nursery areas may actually be less effective as nursery habitat, an important observation that suggests production in these habitats could also be subject to a nursery effect. Secondary production variations are heavily leveraged by density and biomass of juvenile age classes in particular (Valentine-Rose et al. 2007, Benke 2010).

Predicting nursery function and value at large spatio-temporal scales will be exceedingly difficult. For example, higher juvenile densities have been observed in the study area during the wetter, warmer periods of the year (i.e. during the NE monsoon; Kimirei et al. 2011), suggesting that this is the primary recruitment period. Thus, demographic vari- 
ability in time and space could be related to several controlling factors such as tidal regime (especially for mangroves), climate cycles (Hare et al. 1999, Schindler et al. 2008), food availability, alternative habitat/microhabitat availability (Dorenbosch et al. 2004), mortality, and predation (Phelan et al. 2000, Sheaves 2005). Furthermore, survival and somatic growth rates of fish were highly variable across habitats and even within habitat type alone; for example, spatially separated seagrass beds that were unlikely to be connected by daily fish movements due to their large distance of separation often had divergent survival and growth rates for the same species.

We contend that nurseries, and the process of appraising their function and value, are extremely complex and should be handled on a case-by-case basis. It should be acknowledged that this study focused on a specific location (coastal Tanzania) containing a relatively narrow range of habitats in the grand scheme of marine ecology. Thus, similar studies in other oceans, eco-regions, or ecosystems could produce divergent results - e.g. more homogenous levels of food availability, predation, growth, and usage across habitats and age-classes. Based on our knowledge of numerous marine environments, however, this would likely be the extreme exception rather than the rule. Even within our study area, fish demography could be similar across several seagrass beds, but growth rates would differ significantly with food abundance while fish densities differ significantly in accordance with relative predation risk. Thus, some seagrass beds were highly productive (i.e. those with higher growth as well as relative survival rates) while others were not, meaning that their contribution to adult populations was probably much larger.

The current study revealed how the same type of shallow water habitats can often yield highly dissimilar demographic or ecological patterns. Food abundances and relative predation risk (using $L$. fulviflamma as a proxy for all species) varied significantly within and among habitat types and closely mirrored patterns in fish growth, leading to potential differences in productivity and turnover rates. Distance to adjacent reefs and water depth can apparently also actuate demographic change (e.g. by facilitating ingression of large predators). Evaluating the nursery potential of essential juvenile habitats in any sort of official capacity is bound to be highly complex and fraught with uncertainty due to within-habitat variability of nursery role measures, complicated by the fact that these factors are not temporally static. Therefore, occupancy of putative nursery or essential habitat will depend on the quality of these habitats.
Low- and high-quality habitats or habitat patches may thus function as sinks and sources of population propagules, respectively (Hanski 1994, Huijbers et al. 2013). The source habitats help maintain populations in an ecosystem. However, with the current rate of habitat fragmentation and environmental perturbation, habitat quality may continue to deteriorate, which in the near-term is likely to turn more source habitats into sinks (Schreiber \& Kelton 2005). It is therefore necessary to conserve networks of habitat patches (Nagelkerken et al. 2015), including sinks, to ensure sustainability of and continued provision of ecosystem services (Hanski et al. 1996, Palumbi et al. 2009). The identification and valuation of critical habitats remains one of the principal challenges to the conservation and management of marine ecosystems (Duarte et al. 2008). We do not wish to discourage active conservation efforts that employ an approach driven by values based on ecosystems as a whole. Rather, our study suggests that multiple subtypes or patches within the seascape of essential habitat may be needed to more fully sustain coastal populations, perhaps making conservation of mangrove and seagrass habitat more complex than previously thought.

Acknowledgements. This project was funded through WOTRO Science for Global Development by the Netherlands Organisation for Scientific Research (NWO). The field work was supported by a grant from the Schure-BeijerinckPopping Fonds. I.N. was funded by a Vidi grant from NWO. N.S. received funding from FONA. We thank the administration and staff of the Mbegani Fisheries Development Centre (MFDC) for logistical support and research facilities. The staff of the Department of Aquatic Sciences and Fisheries of the University of Dar es Salaam are also thanked for their cooperation and for providing office space and research facilities. We are grateful to Ben Griffioen, Coen Wagner, Michel Trommelen, Piet Blankers, Nanne van Hoytema, Dieuwke, and Peter Smittenaar for their invaluable field assistance, and Hassan and Mmanga for operating the research boat.

\section{LITERATURE CITED}

Adams AJ, Dahlgren CP, Kellison GT, Kendall MS and others (2006) Nursery function of tropical back-reef systems. Mar Ecol Prog Ser 318:287-301

> Almany GR (2004) Differential effects of habitat complexity, predators and competitors on abundance of juvenile and adult coral reef fishes. Oecologia 141:105-113

Aronson RB, Heck KL Jr (1995) Tethering experiments and hypothesis-testing in ecology. Mar Ecol Prog Ser 121: 307-309

> Auster PJ, Malatesta RJ, Donaldson CLS (1997) Distributional response to small-scale habitat variability by early juvenile silver hake, Merluccius bilinearis. Environ Biol Fishes 50:195-200

Baker R, Sheaves M (2005) Redefining the piscivore assem- 
blage of shallow estuarine nursery habitats. Mar Ecol Prog Ser 291:197-213

- Baker R, Sheaves M (2007) Shallow-water refuge paradigm: conflicting evidence from tethering experiments in a tropical estuary. Mar Ecol Prog Ser 349:13-22

Baker R, Sheaves M (2009a) Overlooked small and juvenile piscivores dominate shallow-water estuarine 'refuges' in tropical Australia. Estuar Coast Shelf Sci 85:618-626

Baker R, Sheaves M (2009b) Refugees or ravenous predators: detecting predation on new recruits to tropical estuarine nurseries. Wetl Ecol Manag 17:317-330

Beck MW, Heck KL Jr, Able KW, Childers DL and others (2001) The identification, conservation, and management of estuarine and marine nurseries for fish and invertebrates. Bioscience 51:633-641

Benke A (2010) Secondary production. Nat Educ Knowledge $3: 23$

Blaber SJM (2000) Tropical estuarine fishes: ecology, exploitation and conservation. Fish and Aquatic Resources Series 7. Blackwell Science, Oxford

Carpenter KE (1996) Morphometric pattern and feeding mode in emperor fishes (Lethrinidae, Perciformes). In: Marcus LF, Corti M, Loy A, Naylor G, Slice DE (eds) Advances in morphometrics. Plenum Press, New York, NY, p 479-487

Clarke KR, Warwick RM (2001) Change in marine communities: an approach to statistical analysis and interpretation, $2^{\text {nd }}$ edn. PRIMER-E, Plymouth

Dahlgren CP, Eggleston DB (2000) Ecological processes underlying ontogenetic habitat shifts in a coral reef fish. Ecology 81:2227-2240

$>$ Dahlgren CP, Eggleston DB (2001) Spatio-temporal variability in abundance, size and microhabitat associations of early juvenile Nassau grouper Epinephelus striatus in an off-reef nursery system. Mar Ecol Prog Ser 217:145-156

> Dorenbosch M, Verweij MC, Nagelkerken I, Jiddawi N, van der Velde G (2004) Homing and daytime tidal movements of juvenile snappers (Lutjanidae) between shallow-water nursery habitats in Zanzibar, western Indian Ocean. Environ Biol Fishes 70:203-209

> Dorenbosch M, Grol MGG, Nagelkerken I, van der Velde G (2006) Different surrounding landscapes may result in different fish assemblages in East African seagrass beds. Hydrobiologia 563:45-60

> Dorenbosch M, Grol MGG, de Groene A, van der Velde G, Nagelkerken I (2009) Piscivore assemblages and predation pressure affect relative safety of some back-reef habitats for juvenile fish in a Caribbean bay. Mar Ecol Prog Ser 379:181-196

Duarte CM, Dennison WC, Orth RJW, Carruthers TJB (2008) The charisma of coastal ecosystems: addressing the imbalance. Estuaries Coasts 31:233-238

English S, Wilkinson C, Baker V (1994) Survey manual for tropical marine resources. ASEAN-Australia marine science project: living coastal resources. Australian Institute of Marine Science, Townsville

Faunce CH, Serafy JE (2007) Nearshore habitat use by gray snapper (Lutjanus griseus) and bluestriped grunt (Haemulon sciurus): environmental gradients and ontogenetic shifts. Bull Mar Sci 80:473-495

> Gibson RN (1994) Impact of habitat quality and quantity on the recruitment of juvenile flatfishes. Neth J Sea Res 32: 191-206

Gillanders BM (2006) Seagrasses, fish, and fisheries. In: Larkum AWD (ed) Seagrasses: biology, ecology and con- servation. Springer, Amsterdam, p 503-536

Gillanders BM, Able KW, Brown JA, Eggleston DB, Sheridan PF (2003) Evidence of connectivity between juvenile and adult habitats for mobile marine fauna: an important component of nurseries. Mar Ecol Prog Ser 247:281-295

Grol MGG, Dorenbosch M, Kokkelmans EMG, Nagelkerken I (2008) Mangroves and seagrass beds do not enhance growth of early juveniles of a coral reef fish. Mar Ecol Prog Ser 366:137-146

> Grol MGG, Nagelkerken I, Rypel AL, Layman CA (2011) Simple ecological trade-offs give rise to emergent crossecosystem distributions of a coral reef fish. Oecologia 165:79-88

Grol MGG, Rypel AL, Nagelkerken I (2014) Growth potential and predation risk drive ontogenetic shifts among nursery habitats in a coral reef fish. Mar Ecol Prog Ser 502:229-244

Hammerschlag N, Heithaus MR, Serafy JE (2010) Influence of predation risk and food supply on nocturnal fish foraging distributions along a mangrove-seagrass ecotone. Mar Ecol Prog Ser 414:223-235

> Hanski I (1994) Patch-occupancy dynamics in landscapes. Trends Ecol Evol 9:131-135

Hanski I, Foley P, Hassell M (1996) Random walks in a metapopulation: How much density dependence is necessary for long-term persistence? J Anim Ecol 65:274-282

- Hare SR, Mantua NJ, Francis RC (1999) Inverse production regimes: Alaska and West Coast Pacific salmon. Fisheries 24:6-14

> Huijbers CM, Nagelkerken I, Govers LL, van de Kerk M, Oldenburger JJ, de Brouwer JHF (2011) Habitat type and schooling interactively determine refuge-seeking behavior in a coral reef fish throughout ontogeny. Mar Ecol Prog Ser 437:241-251

Huijbers CM, Nagelkerken I, Debrot AO, Jongejans E (2013) Geographic coupling of juvenile and adult habitat shapes spatial population dynamics of a coral reef fish. Ecology 94:1859-1870

Jones DL, Walter JF, Brooks EN, Serafy JE (2010) Connectivity through ontogeny: fish population linkages among mangrove and coral reef habitats. Mar Ecol Prog Ser 401: 245-258

Kamukuru AT (2009) Trap fishery and reproductive biology of Whitespotted Rabbitfish Siganus sutor (Siganidae), within the Dar es Salaam Marine Reserves, Tanzania. West Indian Ocean J Mar Sci 8:75-86

> Kamukuru AT, Mgaya YD (2004) The food and feeding habits of blackspot snapper, Lutjanus fulviflamma (Pisces: Lutjanidae) in shallow waters of Mafia Island, Tanzania. Afr J Ecol 42:49-58

Kimirei IA, Nagelkerken I, Griffioen B, Wagner C, Mgaya YD (2011) Ontogenetic habitat use by mangrove/seagrass-associated coral reef fishes shows flexibility in time and space. Estuar Coast Shelf Sci 92:47-58

> Kimirei IA, Nagelkerken I, Mgaya YD, Huijbers CM (2013a) The mangrove nursery paradigm revisited: otolith stable isotopes support nursery-to-reef movements by IndoPacific fishes. PLoS ONE 8:e66320

> Kimirei IA, Nagelkerken I, Trommelen M, Blankers P and others (2013b) What drives ontogenetic niche shifts of fishes in coral reef ecosystems? Ecosystems 16:783-796

> Laegdsgaard P, Johnson C (2001) Why do juvenile fish utilise mangrove habitats? J Exp Mar Biol Ecol 257: 229-253

Lugendo BR, Nagelkerken I, Kruitwagen G, van der Velde 
GD, Mgaya YD (2007) Relative importance of mangroves as feeding habitats for fishes: a comparison between mangrove habitats with different settings. Bull Mar Sci 80:497-512

Maceina MJ (1988) A simple grinding procedure for sectioning otoliths. N Am J Fish Manag 8:141-143

Manica A (2002) Filial cannibalism in teleost fish. Biol Rev Camb Philos Soc 77:261-277

Mateo I, Durbin EG, Appeldoorn RS, Adams AJ and others (2010) Role of mangroves as nurseries for French grunt Haemulon flavolineatum and schoolmaster Lutjanus apodus assessed by otolith elemental fingerprints. Mar Ecol Prog Ser 402:197-212

Nagelkerken I (2007) Are non-estuarine mangroves connected to coral reefs through fish migration? Bull Mar Sci 80:595-607

Nagelkerken I (2009) Evaluation of nursery function of mangroves and seagrass beds for tropical decapods and reef fishes: patterns and underlying mechanisms. In: Nagelkerken I (ed) Ecological connectivity among tropical coastal ecosystems. Springer Science+Business Media, Dordrecht, p 357-399

Nagelkerken I, van der Velde G (2004) Relative importance of interlinked mangroves and seagrass beds as feeding habitats for juvenile reef fish on a Caribbean island. Mar Ecol Prog Ser 274:153-159

Nagelkerken I, Dorenbosch M, Verberk WCEP, Cocheret de la Moriniére E, van der Velde G (2000) Importance of shallow-water biotopes of a Caribbean bay for juvenile coral reef fishes: patterns in biotope association, community structure and spatial distribution. Mar Ecol Prog Ser 202:175-192

Nagelkerken I, Sheaves M, Baker R, Connolly RM (2015) The seascape nursery: a novel spatial approach to identify and manage nurseries for coastal marine fauna. Fish Fish doi:10.1111/faf.12057

Nakamura Y, Sano M (2004) Overlaps in habitat use of fishes between a seagrass bed and adjacent coral and sand areas at Amitori Bay, Iriomote Island, Japan: importance of the seagrass bed as juvenile habitat. Fish Sci 70 : 788-803

Nakamura Y, Tsuchiya M (2008) Spatial and temporal patterns of seagrass habitat use by fishes at the Ryukyu Islands, Japan. Estuar Coast Shelf Sci 76:345-356

Olds AD, Connolly RM, Pitt KA, Maxwell PS (2012) Habitat connectivity improves reserve performance. Conserv Lett 5:56-63

Palumbi SR, Sandifer PA, Allan JD, Beck MW and others (2009) Managing for ocean biodiversity to sustain marine ecosystem services. Front Ecol Environ 7:204-211

> Parrish JD (1989) Fish communities of interacting shallowwater habitats in tropical oceanic regions. Mar Ecol Prog Ser 58:143-160

Peterson CH, Black R (1994) An experimentalist's challenge: when artifacts of intervention interact with treatments. Mar Ecol Prog Ser 111:289-297

Phelan BA, Goldberg R, Bejda AJ, Pereira J and others (2000) Estuarine and habitat-related differences in growth rates of young-of-the-year winter flounder (Pseudopleuronectes americanus) and tautog (Tautoga onitis) in three northeastern US estuaries. J Exp Mar Biol Ecol 247:1-28

Pihl L, Modin J, Wennhage H (2005) Relating plaice (Pleuronectes platessa) recruitment to deteriorating habitat quality: effects of macroalgal blooms in coastal nursery grounds. Can J Fish Aquat Sci 62:1184-1193

Rypel AL (2011) River impoundment and sunfish growth. River Res Appl 27:580-590

Rypel AL, Bayne DR (2009) Hydrologic habitat preferences of select southeastern USA fishes resilient to river ecosystem fragmentation. Ecohydrology 2:419-427

Schindler DE, Augerot X, Fleishman E, Mantua N and others (2008) Climate change, ecosystem impacts, and management for Pacific salmon. Fisheries 33:502-506

Schreiber SJ, Kelton M (2005) Sink habitats can alter ecological outcomes for competing species. J Anim Ecol 74: 995-1004

Sheaves M (2001) Are there really few piscivorous fishes in shallow estuarine habitats? Mar Ecol Prog Ser 222: 279-290

> Sheaves M (2005) Nature and consequences of biological connectivity in mangrove systems. Mar Ecol Prog Ser 302:293-305

Sheaves M (2009) Consequences of ecological connectivity: the coastal ecosystem mosaic. Mar Ecol Prog Ser 391: $107-115$

Sheaves M, Johnston R, Connolly RM (2010) Temporal dynamics of fish assemblages of natural and artificial tropical estuaries. Mar Ecol Prog Ser 410:143-157

Sheridan P (1997) Benthos of adjacent mangrove, seagrass and non-vegetated habitats in Rookery Bay, Florida, USA. Estuar Coast Shelf Sci 44:455-469

Shulman MJ (1985) Recruitment of coral reef fishes: effects of distribution of predators and shelter. Ecology 66: 1056-1066

> Sundblad G, Bergström U, Sandström A, Eklöv P (2013) Nursery habitat availability limits adult stock sizes of predatory coastal fish. ICES J Mar Sci 71:672-680

Tupper M, Boutilier RG (1995) Effects of habitat on settlement growth, and postsettlement survival of Atlantic cod (Gadus morhua). Can J Fish Aquat Sci 52:1834-1841

Unsworth RK, De Leon PS, Garrard SL, Jompa J, Smith DJ, Bell JJ (2008) High connectivity of Indo-Pacific seagrass fish assemblages with mangrove and coral reef habitats. Mar Ecol Prog Ser 353:213-224

Unsworth RKF, Garrard SL, Salinas De Léon P, Cullen LC, Smith DJ, Sloman KA, Bell JJ (2009) Structuring of IndoPacific fish assemblages along the mangrove-seagrass continuum. Aquat Biol 5:85-95

Valentine-Rose L, Layman CA, Arrington DA, Rypel AL (2007) Habitat fragmentation decreases fish secondary production in Bahamian tidal creeks. Bull Mar Sci 80: 863-877

> Valiela I, Bowen JL, York JK (2001) Mangrove forests: one of the world's threatened major tropical environments. Bioscience 51:807-815

Verweij MC, Nagelkerken I, de Graaff D, Peeters M, Bakker EJ, van der Velde G (2006) Structure, food and shade attract juvenile coral reef fish to mangrove and seagrass habitats: a field experiment. Mar Ecol Prog Ser 306: 257-268

- Verweij MC, Nagelkerken I, Hans I, Ruseler SM, Mason PRD (2008) Seagrass nurseries contribute to coral reef fish populations. Limnol Oceanogr 53:1540-1547

Wilson KA, Able KW, Heck KL Jr (1990) Predation rates on juvenile blue crabs in estuarine nursery habitats: evidence for the importance of macroalgae (Ulva lactuca). Mar Ecol Prog Ser 58:243-251

Submitted: January 8, 2014; Accepted: September 25, 2014 Proofs received from author(s): December 13, 2014 